\title{
Modeling the Strategic Choice of the Agro-Industrial Enterprises Under the Current State Agricultural Policy
}

\author{
Elena Rodionova \\ Department of Finance, Economics and Organisation of \\ Production \\ Volga State University of Technology \\ Yoshkar-Ola, Russian Federation \\ rodionovaev@volgatech.net
}

\author{
Anna Glebova \\ Department of World Economy and World Finance \\ Financial University under the Government of the Russian \\ Federation \\ Moscow, Russian Federation \\ nauka_rf@mail.ru
}

\author{
Tatiana Baibakova \\ Department of Economics \\ Vyatka State University \\ Kirov, Russian Federation \\ baybakova@vyatsu.ru
}

\begin{abstract}
Modern science has a significant potential of theoretical and applied research concerning the problems of strategic management of socioeconomic systems at different levels. At the same time, sectoral aspects of strategic management in the agricultural sector at the business level require further development, taking into account modern economic conditions, the need for sustainable development of the sector and enhancing the state's influence on its functioning. Because of the specifics of this sector (regarding both the production process and the market operation process), economic performance is more difficult to achieve than in other economic sectors. Therefore, the strategic component of managing the agro-industrial complex is of significant importance. The central element of the strategic management system of an enterprise is the definition of the strategy. That's why the theme of this study seems to be urgent and practically significant. The strategic management researchers have proposed a number of models that allow to make the strategic choice for the enterprise development for the long term on the basis of analyzing certain indicators and factors. There exist some known two-dimensional models (matrices). Unfortunately, they lack the direct connection between the strategy choice based on the matrix and the strategic analysis that precedes the choice and that includes the study of the internal and external environment of the organization. 3-D matrixes increase the validity of the strategic choice but the considered models are not able to provide effective strategic solutions for the enterprises, whose strategic choice due to the industry or other specifics is dominated by the factor that does not have a similar effect in other sectors. We believe that the matrix should also preserve the classical objects of strategic analysis: the external environment and the internal environment,
\end{abstract}

which influence the strategic choice of any enterprise, although it is necessary to make their comprehensive evaluation in view of the influence of the factors which are the most important for a particular industry. Since the strategic development of the agroindustrial complex enterprise is influenced by the agricultural policy of the state, the authors have proposed a 3-D model (threedimensional model) for choosing a strategy taking into account the evaluation of three parameters: the external environment, the internal environment and the existing agricultural policy. Depending on the enterprise's current position, the model allows choosing the right strategy from eight possible ones. The proposed 3-D model for choosing the development strategy of the enterprise of the agro-industrial complex will contribute to the informed strategic decision-making, taking into account the most significant factors that influence the enterprise under the current state agricultural policy.

Keywords: strategy, strategic management, agricultural policy, 3-D model (three-dimensional model)

\section{INTRODUCTION}

The recent years' economic uncertainty has acknowledged to managers the importance of readiness to change and improve the strategy, constantly monitoring and controlling the internal and external forces, learning to adapt to new economic challenges $[1,2]$. That's why strategic management has become one of the most prominent areas of management nowadays. It includes a comprehensive collection of management actions which support companies to keep the organization consistent with the environment and show the 
right way of development. Modern science has a significant potential of theoretical and applied research concerning the problems of strategic management of socioeconomic systems at different levels. At the same time, sectoral aspects of strategic management in the agricultural sector at the business level require further development, taking into account modern economic conditions, the need for sustainable development of the sector and enhancing the state's influence on its functioning.

Sustainable development implies the simultaneous fulfillment of two conditions: the growth of production volumes on the basis of applying innovative technologies and the increase in the competitiveness of the manufactured products [3].

The ability to improve constantly, to support the competitiveness level and to make the necessary innovative changes is one of the most important points of any enterprise activity, including an agro-industrial enterprise, and often it is the decisive factor of the enterprise existence at the market [4$8]$.

The position of agriculture among other sectors of the economy is rather specific because its importance is irreplaceable in terms of nourishing the population and protecting all the components of the environment. Because of the specifics of this sector (regarding both the production process and the market operation process), economic performance is more difficult to achieve than in other economic sectors $[9,10]$. Therefore, the strategic component of managing the agro-industrial complex is of significant importance.

The central element of the strategic management system of an enterprise is the definition of the strategy. That's why the theme of this study seems to be urgent and practically significant. Since the discussions about the strategy nature and content are still going on in the scientific and practical literature [11], in the context of this article, we consider the strategy as "a process of translating perceived opportunity into successful outcomes, by means of purposive action sustained over a significant period of time" [12].

\section{LITERARY REVIEW AND RESEARCH METHODS}

The research materials included the materials of the specialists in strategic management and the information about the activities of enterprises in the agro-industrial complex of different countries that made strategic choices at various stages of their development. In the process of the research we have used abstract-logical and expert methods as a part of the systematic approach to the socio-economic phenomena study.

There exists no universal strategy such as the constant building of larger volumes [13]. There are a lot different strategies, presented in scientific literature and educational material [14-21].

The process of choosing the strategy for an enterprise does not lend itself to detailed formalization, because, like strategic management as a whole, it is realized at the interface of the scientific theory of strategic management and management art, taking into account the characteristics of each enterprise, industry or market situation. Nevertheless, the strategic management researchers have proposed a number of models that allow to make the strategic choice for the enterprise development for the long term on the basis of analyzing certain indicators and factors. There exist some known twodimensional models (matrices) created by I. Ansoff [22], Boston Consulting Group [22], M. Porter [23], General Electric/McKinsey [24], ADL/LC [25], Shell/DPM [22], SIM [26], SPACE [27], and others.

The considered two-dimensional models lack the direct connection between the strategy choice based on the matrix and the strategic analysis that precedes the choice and that includes the study of the internal and external environment of the organization in its generally accepted classical version. Some models use the parameters of the external and (or) internal environment as the analyzed parameters, but they are selective and do not give the overall evaluation of the environment of the enterprise functioning.

3-D matrixes that increase the validity of the strategic choice are presented not so widely. Thus, the 3-D matrix developed by Harbridge House consultants uses risk from the major environmental forces [22] as one of the factors. Russian authors E.Yu. Trifonova and Yu.A. Konovalov [28] have also gone beyond the two-dimensional measurement of the factors affecting the enterprise and they have suggested to consider the economic crisis as an additional parameter (in the author's version - "competence").

In our opinion, the considered models are not able to provide effective strategic solutions for the enterprises, whose strategic choice due to the industry or other specifics is dominated by the factor that does not have a similar effect in other sectors. We believe that the matrix should also preserve the classical objects of strategic analysis: the external environment and the internal environment, which influence the strategic choice of any industry enterprise, although it is necessary to make their comprehensive evaluation in view of the influence of the factors which are the most important for a particular industry.

\section{RESULTS AND DISCUSSION}

On the basis of the above stated, in the 3-D model of the strategic choice of the enterprises of the agro-industrial complex we propose to include the following parameters "External environment", "Internal environment" and "Agricultural policy" (including government support for the agro-industrial complex) as the most significant factor influencing the agro-industrial complex development.

In fact, government support for the agro-industrial complex is used in all developed countries: its need is caused by the specific features inherent to this sector of economy. This factor plays extremely significant role at the development stage, which is aimed at the significant increase in labor productivity, technological transformation of the industry, increasing product competitiveness and expanding its presence at external agrifood markets. The world experience shows that the agriculture achievements of different countries are the 
the market for agricultural products, raw materials and food $\left(Z_{3}\right)$, government support for innovation and digital technologies in the agro-industrial complex $\left(\mathrm{Z}_{4}\right)$.

The coordinate P1 in the 3-D model is calculated according to the following formula:

$$
\mathrm{P} 1=\mathrm{a}_{1} \cdot \mathrm{X}_{1}+\mathrm{a}_{2} \cdot \mathrm{X}_{2}+\mathrm{a}_{3} \cdot \mathrm{X}_{3}+\mathrm{a}_{4} \cdot \mathrm{X}_{4}, 0<\mathrm{P} 1<10
$$

where $a_{i}$ is the weighing coefficient of the indicator $X_{i}$ significance, determined by the expert method, $0<a_{i}<1 ; X_{i}-$ the indicator values, $0<\mathrm{X}_{\mathrm{i}}<10$.

The coordinate P2 in the 3-D model is calculated according to the following formula:

$$
\mathrm{P} 2=\mathrm{b}_{1} \cdot \mathrm{Y}_{1}+\mathrm{b}_{2} \cdot \mathrm{Y}_{2}+\mathrm{b}_{3} \cdot \mathrm{Y}_{3}+\mathrm{b}_{4} \cdot \mathrm{Y}_{4}, 0<\mathrm{P} 2<10
$$
taking into account the weighing coefficients of the estimated parameters. We agree with this approach. However, taking into account the importance of various factors of the external and internal environment of the enterprises of the agroindustrial complex, as well as modern agricultural policy, we suggest evaluating the following parameters by an expert method:

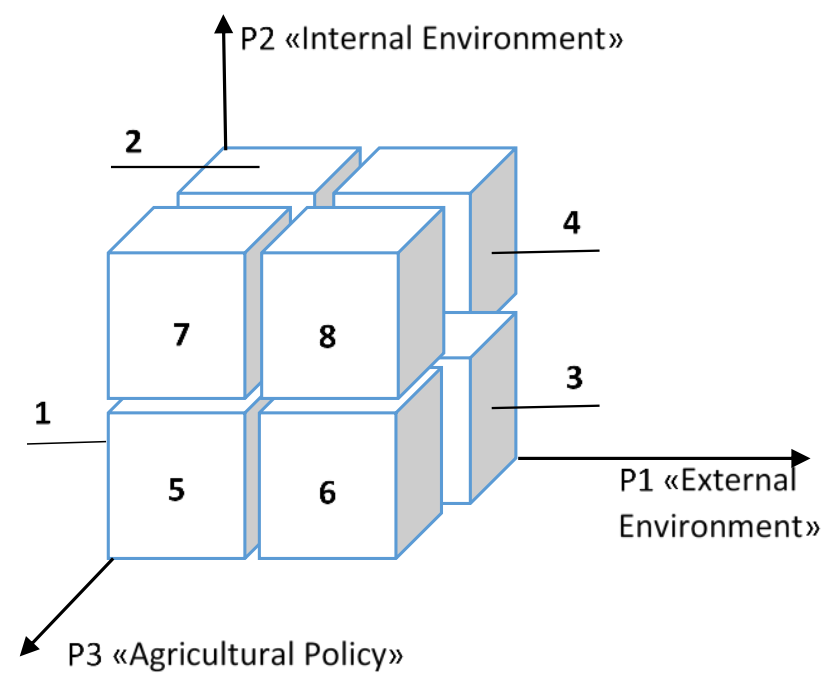

Fig. 1. The 3-D model of the strategic choice of the enterprises of the agroindustrial complex under the modern agricultural policy

1) P1 "External environment", which characterizes opportunities and threats for the enterprise from the external environment: socioeconomic factors $\left(\mathrm{X}_{1}\right)$, technological factors $\left(\mathrm{X}_{2}\right)$, market and competitive situation $\left(\mathrm{X}_{3}\right)$, climatic factors $\left(\mathrm{X}_{4}\right)$.

2) P2 "Internal environment", which characterizes the enterprise strengths and weaknesses: financial and economic condition $\left(\mathrm{Y}_{1}\right)$, level of innovation development $\left(\mathrm{Y}_{2}\right)$, market position $\left(\mathrm{Y}_{3}\right)$, level of strategic management $\left(\mathrm{Y}_{4}\right)$.

3) P3 "Agricultural Policy", which characterizes the agricultural policy influence on the agro-industrial enterprises development: government support for agricultural production $\left(Z_{1}\right)$, government support for food exports $\left(Z_{2}\right)$, regulation of where $b_{j}$ is the weighing coefficient of the indicator $Y_{j}$ significance, determined by the expert method, $0<b_{j}<1 ; Y_{j}-$ the indicator values, $0<\mathrm{Y}_{\mathrm{j}}<10$.

The coordinate P3 in the 3-D model is calculated according to the following formula:

$$
\mathrm{P} 3=\mathrm{c}_{1} \cdot \mathrm{Z}_{1}+\mathrm{c}_{2} \cdot \mathrm{Z}_{2}+\mathrm{c}_{3} \cdot \mathrm{Z}_{3}+\mathrm{c}_{4} \cdot \mathrm{Z}_{4}, 0<\mathrm{P} 3<10
$$

where $c_{k}$ is the weighing coefficient of the indicator $Z_{k}$ significance, determined by the expert method, $0<c_{k}<1 ; Z_{k}-$ the indicator values, $0<\mathrm{Z}_{\mathrm{k}}<10$.

The areas boundaries of the 3-D model are presented in Table I.

TABLE I. COMPARATIVE ANALYSIS OF INNOVATION AND DIVERSIFICATION CHARACTERISTICS (COMPOSED BY AUTHORS)

\begin{tabular}{|c|l|}
\hline $\begin{array}{c}\text { The Area of } \\
\text { the Model }\end{array}$ & \multicolumn{1}{|c|}{ The Areas Boundaries } \\
\hline 1 & $\{\mathrm{Q}(\mathrm{P} 1, \mathrm{P} 2, \mathrm{P} 3) ; 0<\mathrm{P} 1<5 ; 0<\mathrm{P} 2<5 ; 0<\mathrm{P} 3<5\}$ \\
\hline 2 & $\{\mathrm{Q}(\mathrm{P} 1, \mathrm{P} 2, \mathrm{P} 3) ; 0<\mathrm{P} 1<5 ; 5<\mathrm{P} 2<10 ; 0<\mathrm{P} 3<5\}$ \\
\hline 3 & $\{\mathrm{Q}(\mathrm{P} 1, \mathrm{P} 2, \mathrm{P} 3) ; 5<\mathrm{P} 1<10 ; 0<\mathrm{P} 2<5 ; 0<\mathrm{P} 3<5\}$ \\
\hline 4 & $\{\mathrm{Q}(\mathrm{P} 1, \mathrm{P} 2, \mathrm{P} 3) ; 5<\mathrm{P} 1<10 ; 5<\mathrm{P} 2<10 ; 0<\mathrm{P} 3<5\}$ \\
\hline 5 & $\{\mathrm{Q}(\mathrm{P} 1, \mathrm{P} 2, \mathrm{P} 3) ; 0<\mathrm{P} 1<5 ; 0<\mathrm{P} 2<5 ; 5<\mathrm{P} 3<10\}$ \\
\hline 6 & $\{\mathrm{Q}(\mathrm{P} 1, \mathrm{P} 2, \mathrm{P} 3) ; 5<\mathrm{P} 1<10 ; 0<\mathrm{P} 2<5 ; 5<\mathrm{P} 3<10\}$ \\
\hline 7 & $\{\mathrm{Q}(\mathrm{P} 1, \mathrm{P} 2, \mathrm{P} 3) ; 0<\mathrm{P} 1<5 ; 5<\mathrm{P} 2<10 ; 5<\mathrm{P} 3<10\}$ \\
\hline 8 & $\begin{array}{l}\{\mathrm{Q}(\mathrm{P} 1, \mathrm{P} 2, \mathrm{P} 3) ; 5<\mathrm{P} 1<10 ; 5<\mathrm{P} 2<10 ; 5<\mathrm{P} 3< \\
10\}\end{array}$ \\
\hline
\end{tabular}

The features of possible strategy types are presented in Table II.

The order of the strategies in the 3-D model reflects the quantitative and qualitative composition of the factors affecting the enterprise. For example, the area No. 1 of the 3$\mathrm{D}$ model implies the use of the retrenchment strategy, since in this case the enterprise operates in very unfavorable 
TABLE II. TYPES OF STRATEGIES FOR THE ENTERPRISES OF THE AGRO-INDUSTRIAL COMPLEX

\begin{tabular}{|c|c|c|c|c|}
\hline & Strategy & Strategy type & Characteristics of the environment & Recommended business line \\
\hline \multirow{4}{*}{ 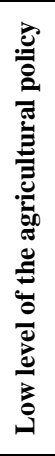 } & 1 & $\begin{array}{l}\text { Retrenchment } \\
\text { strategy }\end{array}$ & $\begin{array}{l}\text { The enterprise operates in very unfavorable environment } \\
\text { according to all three parameters }\end{array}$ & $\begin{array}{l}\text { The refusal of a long-term view on the business } \\
\text { and even the complete liquidation of the } \\
\text { enterprise }\end{array}$ \\
\hline & 2 & $\begin{array}{l}\text { Stability } \\
\text { strategy }\end{array}$ & $\begin{array}{l}\text { The enterprise has sufficiently high internal potential, but the } \\
\text { environmental conditions are unsatisfactory; besides, for some } \\
\text { reasons the enterprise cannot use the state support }\end{array}$ & $\begin{array}{l}\text { Decrease in the rate of revenues fall from the } \\
\text { negative effects of the external environment by } \\
\text { reducing costs and restructuring }\end{array}$ \\
\hline & 3 & $\begin{array}{l}\text { Integration } \\
\text { strategy }\end{array}$ & $\begin{array}{l}\text { The enterprise does not fully use the resources of its internal } \\
\text { environment, there is serious internal potential. Favorable } \\
\text { characteristics of the environment give the firm additional } \\
\text { opportunities }\end{array}$ & $\begin{array}{l}\text { The enterprise development due to controlling the } \\
\text { strategically important links in the chain of } \\
\text { production and sales of products through vertical } \\
\text { regressive, vertical progressive and horizontal } \\
\text { integration }\end{array}$ \\
\hline & 4 & $\begin{array}{l}\text { The strategy of } \\
\text { concentrated } \\
\text { growth }\end{array}$ & $\begin{array}{l}\text { The enterprise operates in favorable environment, the } \\
\text { parameters of the internal and external environment are } \\
\text { maximal or close to maximum. The state support is insufficient }\end{array}$ & $\begin{array}{l}\text { Using the potential of the internal and external } \\
\text { environment in order to strengthen the enterprise } \\
\text { position at the existing (domestic) market }\end{array}$ \\
\hline \multirow{4}{*}{ 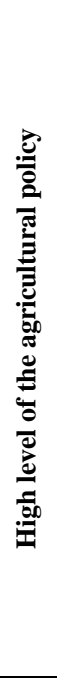 } & 5 & $\begin{array}{l}\text { The strategy of } \\
\text { financial } \\
\text { recovery }\end{array}$ & $\begin{array}{l}\text { The high level of the agricultural policy influence and the } \\
\text { unfavorable internal and external environment make this } \\
\text { strategy use extremely unstable: the enterprise quickly moves } \\
\text { to strategy } 1 \text { with subsequent liquidation, or to strategy } 6 \text { with } \\
\text { the prospects for internal growth }\end{array}$ & $\begin{array}{l}\text { Developing the measures to restore its paying } \\
\text { capacity (if necessary) and to support effective } \\
\text { economic activities }\end{array}$ \\
\hline & 6 & $\begin{array}{l}\text { The potential } \\
\text { growth strategy }\end{array}$ & $\begin{array}{l}\text { The indirect government regulation stabilizes the parameters of } \\
\text { the environment, increases their quantitative and qualitative } \\
\text { characteristics. Due to the high performance of parameters P1 } \\
\text { and P3, the enterprise can increase its internal potential and } \\
\text { achieve growth at the expense of internal funds }\end{array}$ & $\begin{array}{l}\text { The enterprise orientation to the significant } \\
\text { increase in market share, and to the increase in } \\
\text { the internal environment potential }\end{array}$ \\
\hline & 7 & $\begin{array}{l}\text { Diversification } \\
\text { strategy }\end{array}$ & $\begin{array}{l}\text { The enterprise makes the most of its strengths, neutralizing its } \\
\text { weaknesses wherever possible. The external environment is } \\
\text { not favorable, but the high level of the parameter } \mathrm{P} 3 \text { promotes } \\
\text { its growth. The direct government support allows the company } \\
\text { to develop as part of this strategy with the further transition to } \\
\text { strategy } 8 \text { (with effective government regulation of the external } \\
\text { environment) }\end{array}$ & $\begin{array}{l}\text { Entering into a new market or industry in which } \\
\text { the business doesn't currently operate. It is } \\
\text { realized through horizontal, conglomerative and } \\
\text { vertical diversification }\end{array}$ \\
\hline & 8 & $\begin{array}{l}\text { Intensification } \\
\text { strategy }\end{array}$ & $\begin{array}{l}\text { The enterprise uses the maximum number of resources for all } \\
\text { three parameters, which gives an opportunity for its further } \\
\text { intensive growth }\end{array}$ & $\begin{array}{l}\text { Using the potential of the internal and external } \\
\text { environment in order to strengthen the position at } \\
\text { the existing (internal) market and to get access to } \\
\text { a new (external) market }\end{array}$ \\
\hline
\end{tabular}

environment according to all three parameters: $\{\mathrm{Q}(\mathrm{P} 1, \mathrm{P} 2$, $\mathrm{P} 3) ; 0<\mathrm{P} 1<5 ; 0<\mathrm{P} 2<5 ; 0<\mathrm{P} 3<5\}$. And vice versa, the area No. 8 of the 3-D model implies the use of the intensification strategy, since in this case the enterprise uses the maximum number of resources according to all three parameters: $\{\mathrm{Q}(\mathrm{P} 1, \mathrm{P} 2, \mathrm{P} 3) ; 5<\mathrm{P} 1<10 ; 5<\mathrm{P} 2<10 ; 5<\mathrm{P} 3$ $<10\}$. Thus, in Tables I and II, all the strategies are located with the increase of the quantitative and qualitative characteristics of the environment in which the enterprise of the agro-industrial complex operates.

The first block of the strategies (strategies 1-4) is characterized by the complete absence of the state support or its minimum presence - the plane of parameters P1 "External environment" and P2 "Internal environment".

The second block of the strategies (strategies 5-8) implies the adjustment of the current situation at the enterprise by direct or indirect state regulation within the framework of the agricultural policy implemented in the country (parameter P3 "Agricultural policy").

\section{CONCLUSION}

We consider that the proposed 3-D model for choosing the development strategy of the enterprises of the agro-industrial complex will contribute to the informed strategic decision- making, taking into account the most significant factors that influence the enterprise under the current state agricultural policy.

For example, the modern Russian agricultural policy, aimed at import substitution and creation of a highly productive export-oriented sector in the agro-industrial complex, forms the field of choosing the strategies located at areas 5-8. The trajectory of the enterprises strategic development in these areas of the model is associated with various ways of economic growth leading to the improvement of the enterprise internal potential, to the output increase, to the improvement of the products competitiveness, to the expansion of its product range and to the development of an export market in short or long-term.

\section{ACKNOWLEDGMENT}

Authors thank the anonymous peer reviewers for their insightful comments and suggestions.

\section{REFERENCES}

[1] A. Čuić Tanković, "Defining strategy using vision and mission statements of croatian organizations in times of crisis", in Ekonomska istraživanja, Economic Research Special Issue, The 6th International 
[15] A. Pehrsson, "The "Strategic States Model": strategies for business growth“, in Business Strategy Series, Vol. 8, Issue 1, pp. 58-63, 2007.

[16] F. Schiavone, "Strategic reactions to technology competition: A decision-making model", in Management Decision, Vol. 49, Issue 5, pp. 801-809, 2011.

[17] A.K. Srivastava, and Sushil, "Modeling strategic performance factors for effective strategy execution", in International Journal of Productivity and Performance Management, Vol. 62, Issue 6, pp. 554-582, 2013.

[18] Y.E. Tasgit, F.K. SSentrük, and E. Ergün, "Corporate Culture and Business Strategy: Which strategies can be applied more easily in which culture?", in International Journal of Business and Social Science, Vol. 8, No. 6, pp. 80-91, 2017.

[19] E.V. Rodionova, "Integration processes in the meat products subcomplex of the agro-industrial complex of Russia: results, specifics and ways of development", in Economic and Social Changes; Facts, Trends, Forecast, Vol. 11, No. 2, pp. 144-159, 2018.

[20] M.E. Porter, and M.R. Kramer, "Creating Shared Value", in Lenssen G., Smith N. (eds) Managing Sustainable Business, Dordrecht, Springer, p. 681, 2019.

[21] D. Hussey, "Strategic management: from theory to implementation". 4th ed. Butterworth-Heinemann, Oxford, 1998, p. 704.

[22] M.E. Porter, "Competitive Advantage: Creating and sustaining superior performance". Free Press, New York, 1985, p. 658.

[23] K. Coyne, "Enduring Ideas: The GE-McKinsey nine-box matrix", 2008. Available at: https://www.mckinsey.com/business-functions/strategyand-corporate-finance/our-insights/enduring-ideas-the-ge-and-mckinseynine-box-matrix" [Accessed: 10 September 2019].

[24] V. Van Vliet, "ADL Matrix", 2011. Available at: https://www.toolshero.com/strategy/adl-matrix/ [Accessed: 10 September 2019].

[25] S. Zakeri, Y. Yang, and M. Hashemi, "Grey strategies interaction model", in Journal of Strategy and Management, Vol. 12, Issue 1, pp. 30-60, 2019.

[26] L. Louw, and L. Radder, "SPACE Matrix: A tool for calibrating competition", in Social sciences, No. 4(31), pp. 549 - 559, 1998.

[27] E.Yu.Trifonova, and Yu.A. Konovalov, "Trehmernaya model razvitia predpriatia v usloviah krizisa", in Rossiiskoe predprinimatelstvo, No. 4(1), pp. 52-57, 2010.

[28] M.Y. Veselovsky, P.P. Pilipenko, V.G. Savenko, A.G. Glebova, and L.A. Shmeleva, "The organization of the innovation transfer in the agro-industrial complex of Russia", in European Research Studies Journal, Vol. XX, Issue 3A, pp. 484-499, 2017.

[29] S. Wiggins, J. Farrington, G. Henley, N. Grist, and A. Locke, "Agricultural development policy: a contemporary agenda. Background Paper for GIZ“, 2013. Available at: https://www.giz.de/expertise/downloads/giz2013-en-odi-agriculturaldevelopment-policy-contemporary-agenda.pdf [Accessed: 10 September 2019]. 